\title{
MARINE SHRIMP CULTIVATED AT DIFFERENT DENSITIES AND FEEDING REGIMENS IN OLIGOHALINE WATERS ${ }^{1}$
}

\author{
MAURÍCIO NOGUEIRA DA CRUZ PESSÔA ${ }^{2 *}$, JULIANA MARIA ADERALDO VIDAL ${ }^{2}$, UGO LIMA SILVA $^{2}$, PAULO DE \\ PAULA MENDES ${ }^{3}$
}

\begin{abstract}
The cultivation of Litopenaeus vannamei has increased in inland areas by using low salinity waters. Cultivation techniques in coastal waters are well developed, however, studies for low salinity conditions are needed, especially regarding the ideal ionic composition of water and its effects on the zootechnical indices. Brazil has adopted this strategy and the semiarid region showed great potential due to its favorable climate and water conditions. Thus, experimental cultivations were conducted in Serra Talhada, State of Pernambuco, in order to evaluate the influence of two feeding strategies (with and without feeding) and three cultivation densities (5, 10 and 15 shrimps $\mathrm{m}^{-2}$ ), on the production variables of this species. Three ponds of $280 \mathrm{~m}^{2}$ were built, in which six nursery nets of $20 \mathrm{~m}^{2}$ were installed. The cultivation was performed with juvenile shrimps of $8.53 \mathrm{~g}$ and lasted 50 days. The animals were fed twice a day with commercial feed containing $25 \%$ of crude protein. The water quality (salinity $\sim 1.0 \mathrm{~g} \mathrm{~L}^{-1}$, temperature $\sim 28.09^{\circ} \mathrm{C}, \mathrm{pH}$ 8.48) and the shrimp growth were monitored with weekly biometry during the cultivation. A significant difference was found only in the treatment without feeding with 15 shrimps $\mathrm{m}^{-2}$, the average final weight of all treatments ranged from $13.16 \pm 1.33 \mathrm{~g}$ to $15.50 \pm 1.66 \mathrm{~g}$. The survival rates were high in the treatments with feeding and its variation between treatments was $60.56 \pm 6.76 \%$ and $83.00 \pm 4.00 \%$.
\end{abstract}

Key words: Litopenaeus vannamei. Low salinity. Semiarid.

\section{CULTIVO DO CAMARÃO MARINHO, SOB DIFERENTES DENSIDADES DE ESTOCAGEM E ALIMENTAÇÃO, EM ÁGUAS OLIGOHALINAS}

RESUMO - O cultivo do Litopenaeus vannamei vem sendo ampliado nas áreas interioranas, fazendo uso de águas com baixa salinidade. As técnicas de cultivo em águas costeiras já estão bastante desenvolvidas, porém em condições de baixa salinidade são necessários vários estudos, como a composição iônica ideal da água e seus efeitos sobre os índices zootécnicos. O Brasil tem adotado essa estratégia e o semiárido surge como uma região de grande potencial, já que dispõe de clima e condições hídricas favoráveis. Desta forma, cultivos experimentais foram realizados no município de Serra Talhada - PE, com o objetivo de avaliar a influência de duas estratégias de alimentação (com e sem ração) e três densidades de cultivo (5, 10 e 15 camarões. $\mathrm{m}^{-2}$ ), nas variáveis de produção dessa espécie. Para tanto foram utilizados três viveiros escavados de $280 \mathrm{~m}^{2}$, onde foram instalados seis cercados de telas medindo $20 \mathrm{~m}^{2}$. A estocagem foi realizada com juvenis de $8,53 \mathrm{~g}$, o cultivo teve duração de 50 dias e os animais foram alimentados duas vezes por dia com ração comercial, contendo $25 \%$ de proteína bruta, monitorada a qualidade da água (salinidade $\pm 1,0$ g. $L^{-1}$; temperatura $\pm 28,09{ }^{\circ} \mathrm{C} ; \mathrm{pH} \pm 8,48$; entre outros) e crescimento dos camarões durante o cultivo, com biometrias semanais. Foi detectada diferença significativa apenas no tratamento sem ração com 15 camarões.m ${ }^{-2}$, o peso médio final entre todos os tratamentos variou de $13,16 \pm 1,33 \mathrm{~g}$ a 15,50 $\pm 1,66 \mathrm{~g}$. As taxas de sobrevivências foram melhores nos tratamentos com ração, a variação entre os tratamentos foi de $60,56 \pm 6,76 \%$ e $83,00 \pm 4,00 \%$.

Palavras-chave: Litopenaeus vannamei. Baixa salinidade. Semiárido.

\footnotetext{
*Corresponding author

${ }^{1}$ Received for publication in 10/06/2014; accepted in 04/11/2016.

Paper extracted from the doctoral thesis of first author.

${ }^{2}$ Academic Unity of Serra Talhada, Universidade Federal Rural de Pernambuco, Serra Talhada, PE, Brazil; mauriciopes@yahoo.com.br, julymav@yahoo.com.br, ugolimas@gmail.com.

${ }^{3}$ Department of Fishing and Aquiculture, Universidade Federal Rural de Pernambuco, Recife, PE, Brazil; paulo_ufrpe@yahoo.com.br.
} 


\section{INTRODUCTION}

The cultivation of the shrimp Litopenaeus vannamei was carried out exclusively in coastal areas until the early 90 s, with high implementation costs due to the high values of land and multiple uses of these areas.

Several studies were conducted to mitigate these problems, describing strategies of alternative cultivation, such as the shrimp farming in inland areas, using oligohaline waters, since the value of lands in these regions is much lower than the value of lands in the coast. According to the survey conducted by the real estate sector in the State of Pernambuco, the price of a hectare in inland areas is $1.16 \%$ of the value of one hectare in the coastal region of the state.

This species has characteristic euryhaline, tolerates a wide range of salinity (YE et al., 2009), however, there are few researches on cultivation of $L$. vannamei concerning low salinity waters (DAVIS et al., 2005).

According to the FAO (2014), the production of L. vannamei in the world in 2012 was about $3,178,721.1 \mathrm{Mg}$, with about $696,051.5 \mathrm{Mg}(21.89 \%$ of the world's production) produced in low salinity water.

Brazil and other countries has adopted the strategy of cultivating this species in regions with low salinity waters. According to the Brazilian Association of Shrimp Breeders (ABCC, 2013), about $28 \%$ of the shrimp Brazilian farms (5,000 ha) is using wells, ponds or rivers with oligohaline water and accounting for $25.06 \%$ of national production.

The good zootechnical results of the $L$. vannamei grown in oligohaline environments have encouraged this business in inland areas. Numerous water bodies (small ponds) and thousands of wells were constructed in order to minimize the problems of seasonal droughts in Brazil, especially in its semiarid region. Salinization of water is common in these environments because the rocky composition of the soil in this region, which is rich in salts that accumulate in these water bodies by leaching and runoff, turning them unfit for human consumption (COSTA; CIRILO, 2010).

The Geological Survey of Brazil (CPRM) analyzed the water quality and registered about 22,000 wells in Pernambuco in 2005. More than 2,700 wells were registered in the Pajeú River basin alone, but only $29.4 \%$ were registered as fresh water, the others were registered as brackish $(45.8 \%)$ and saline $(24.8 \%)$ waters, about $41 \%$ were abandoned, not ready or unused, mainly due to the poor quality of water for human or animal consumption (CPRM, 2005).

Some important negative characteristics must be taken into account at implementing a shrimp farming in the Brazilian semiarid region, such as low water availability for large enterprises, low financial capacity of the owners of lands that have water resources, low technical and practical knowledge of the future shrimp farmers and distances from the input suppliers. On the other hand, there are some positive characteristics, such as good consumer market, high commercial value of the product, cultural aspects of shrimp farmers, which are focused on subsistence crops and livestock at small scales, availability of workers, training of workers who know the region characteristics, and the water characteristics in the region (high temperature, alkalinity, hardness and concentrations of ions).

Considering these characteristics, researchers on alternatives for cultivations that has low production cost, low cultivation densities, low feeding cost, or even cultivations that can be grown without feed (since they represent up to $60 \%$ of the production cost), are needed for the Brazilian semiarid region (CUZON et al., 2004). In this context, the objective of this work was to evaluate the zootechnical performance of the marine shrimp Litopenaeus vannamei grown in oligohaline water with two feeding management strategies.

\section{MATERIAL AND METHODS}

Experiment location

The experiment was conducted in the Pisciculture Station of the Academic Unit of Serra Talhada, State of Pernambuco, Brazil (07 $56^{\prime} 00^{\prime \prime} \mathrm{S}$, $38^{\circ} 17^{\prime} 14^{\prime \prime} \mathrm{W}$ and altitude of $500 \mathrm{~m}$ ). Four ponds of $280 \mathrm{~m}^{2}$ were built and filled with water from the reservoir Saco-1 that has capacity of $36,000,000 \mathrm{~m}^{3}$ of water. During the experimental phase the water salinity of the reservoir was close to $1.0 \mathrm{~m} \mathrm{~L}^{-1}$.

Acquisition of post-larvae and development of juvenile shrimps

Post-larvae of shrimps L. vannamei with 13 days of life were acquired from a commercial laboratory of the State of Rio Grande do Norte. The post-larvae were transported in water with salinity of $4.0 \mathrm{~g} \mathrm{~L}^{-1}$ to the experiment location and then acclimated to the local water salinity $\left(0.5 \mathrm{~g} \mathrm{~L}^{-1}\right)$ for one week in primary nursery systems, by keeping them in two fiberglass tanks $\left(1.0 \mathrm{~m}^{3}\right)$, at density of 30 post-larvae $\mathrm{L}^{-1}$, and exchanging $10 \%$ of the water every 6 hours for seven days. The hydrologic variables $(\mathrm{pH}$, salinity, conductivity, temperature and dissolved oxygen) were controlled in this period every 2 hours and the Post-larvae fed every three hours (feed with $45 \%$ of gross protein).

The post-larvae were then transferred to a nursery pond of $280 \mathrm{~m}^{2}$, where they were maintained for 90 days at initial density of 160 individuals $\mathrm{m}^{-2}$, until reaching average weight of $8.53 \pm 0.12 \mathrm{~g}$. In this nursery, the shrimps were fed four times a day with a balanced feed containing $40 \%$ crude protein, which was broadcasting by hand in the first 20 days, and 
thereafter, with a feed containing $32 \%$ crude protein supplied in food trays, adjusted according to the consumption observed.

Experimental design
Three ponds were prepared to receive the juveniles $(8.53 \pm 0.12 \mathrm{~g})$, each pond testing three crop densities $\left(5,10\right.$ and 15 individuals $\left.\mathrm{m}^{-2}\right)$ subjected to the use or not of feed. the abbreviations used for each treatment is presented in Table 1.

Table 1. Experimental design (densities and treatments with and without feeding).

\begin{tabular}{ccc}
\hline DENSITIES & \multicolumn{2}{c}{ TREATMENTS } \\
\hline 5 shrimp m $^{-2}$ & WITH FEED & WITHOUT FEED \\
10 shrimp $\mathrm{m}^{-2}$ & WIF05 & WOF05 \\
15 shrimps m $^{-2}$ & WIF10 & WOF10 \\
\hline
\end{tabular}

The preparation of nurseries was performed with interventions on the soil aiming for its standardization and fertilization, by leveling their bottom and applying fertilization with wheat bran $\left(25 \mathrm{~g} \mathrm{~m}^{-2}\right)$ to improve the proliferation of pre- existing benthic community (CAMPOS et al., 2009). Six nursery nets of $20 \mathrm{~m}^{2}$, made of plastic screen with mesh of $6 \mathrm{~mm}$, were installed in each nursery (Figure 1). The positioning of each treatment (density and the use of feed) was randomly chosen.

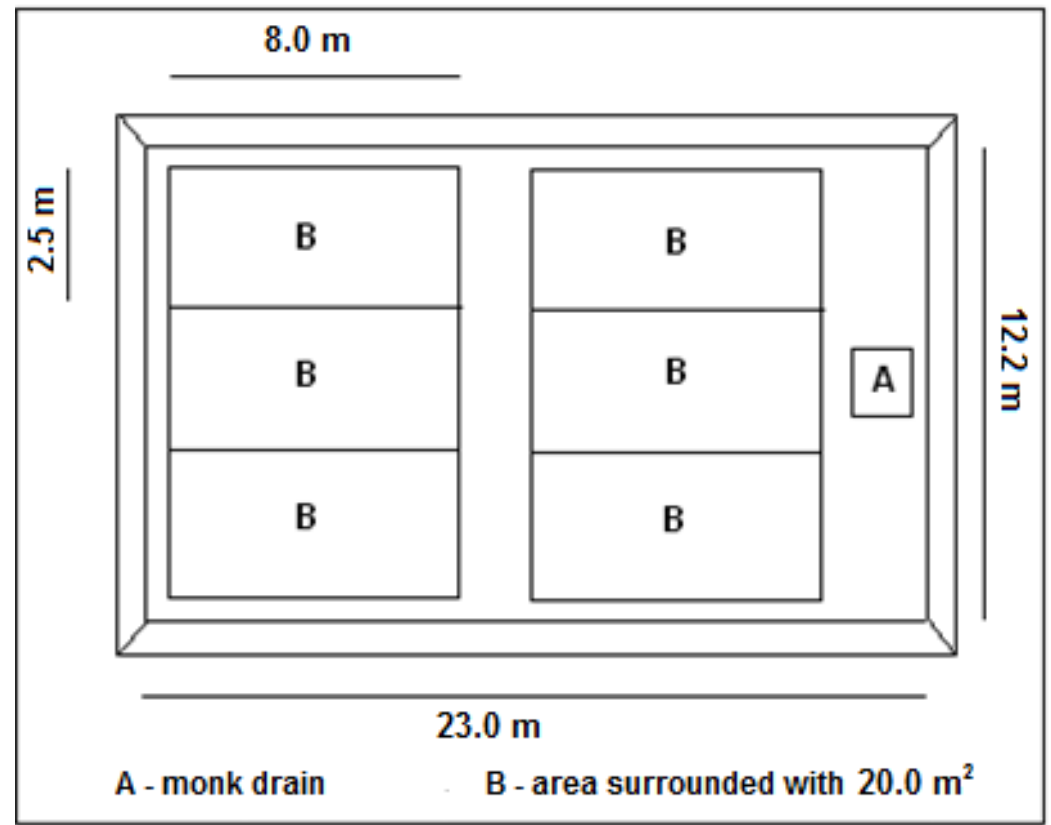

Figure 1. Dising of the experimental nursery.

Feeding management and control of hydrological parameters

The feeding was performed 2 times a day (treatments with feed) and the feed amount estimated according to the consumption observed in the feed trays. A commercial feed with $25 \%$ crude protein was used. The feed residues in the trays were removed to prevent damage to the water quality. The water quality variables (temperature, $\mathrm{pH}$, salinity, dissolved oxygen and electric conductivity) were measured daily using a multi-parameter device in nine different times (01:00; 03:00; 05:00; 08:00; $11: 00 ; 14: 00 ; 17: 00 ; 20: 00$ and 23:00h).

Water samples were collected at 1, 15, 30 and 45 days of cultivation for analysis of total alkalinity, total hardness, total ammonia, orthophosphate, nitrite, nitrate, chlorophyll-a, pheophytin, silica and ionic composition (total chlorides, total sulfates, potassium, sodium, calcium and magnesium).
Study period and monitoring of the shrimp weight gain

The cultivation period was 50 days. Four samples were collected at 1, 15, 30, 45 days of cultivation. The samples consisted of 3,6 and 9 shrimps from the densities of 5, 10 and 15 shrimps $m$ -2 , respectively. The shrimps were placed in plastic bags, identified and individually weighed on a digital scale with a precision of $0.0001 \mathrm{~g}$. The results were recorded in spreadsheets for further analysis.

Statistical analysis

The following mathematical model were used to assess the influence of the use of feed and three cultivation densities:

$$
V R_{j}=\beta_{0}+\sum_{i=1}^{n} \beta_{i} X_{i j}+\varepsilon_{j}
$$

Rev. Caatinga, Mossoró, v. 29, n. 3, p. 700 - 708, jul. - set., 2016 
where $V R=$ variable response (weight and survival); $b_{0}, b_{1}, b_{2}, \ldots, b_{n}=$ parameters of the model; $X=$ variable of management (use of feed, cultivation density, interaction and block); $i=$ cultivation variable; $j=$ observation number $\varepsilon=$ error associated with observation with parameters $\varepsilon \sim \mathrm{N}\left(0, \sigma^{2}\right)$.

The method of least squares (ZAR, 2010) was used to estimate the model parameters $\left(\beta_{0,1,2,3 \ldots n}\right)$. The stepwise process (selection of variables) (MENDES, et al. 2006) was used to assess the influence ( $p$ $<0.05)$ of each variable of the model. The robustness of the model based on the statistic F of Snedecor, value of the probability of $F, R^{2}$, normality of errors (Shapiro-Wilk) and number of outliers were evaluated at the end of the process.

The weight as a function of time of cultivation was evaluated using the model $P_{\mathrm{i}}=\beta_{0}+\beta_{1} T_{\mathrm{i}}+\varepsilon_{\mathrm{i}}$ for each treatment, where $\mathrm{P}=$ weigh; $\beta_{0}$ and $\beta_{1}=$ parameters of the model; $\mathrm{T}=$ cultivation time and $\varepsilon=$ error with distribution $\mathrm{N}=(0, \sigma 2)$. The " $t$ " test was used, evaluating possible differences between treatments to compare the models (ZAR, 2010). In this model, the estimative of $\beta_{1}$ represent the daily growth rate (DGR), thus, the same test was used to discern possible differences in this parameter of cultivation.

\section{RESULTS AND DISCUSSION}

The cultivation of $L$. vannamei with initial weight of $8.53 \pm 0.12 \mathrm{~g}$ in oligohaline water for 50 days in Pernambuco, at densities of 5, 10 and 15 shrimps $\mathrm{m}^{-2}$ and with and without the use of feed resulted in a final average weight from $13.16 \pm 1.33 \mathrm{~g}$ to $15.50 \pm 1.66 \mathrm{~g}$. The average effect of feed and cultivation density did not influence the shrimp final average weight, however, a significant difference was found $(p \geq 0,05)$ in the density of 15 shrimps $\mathrm{m}^{-2}$ with and without feed (Table 2). In general, significant difference was detected between treatments, however, a reduction in the final average weight gain was found without the use of feed and with increasing in cultivation density. This result may be related to high levels of confidence intervals (average of $9.68 \%$ ) of the estimated averages.

Table 2. Final average weight (g) depending on the supplying or not of feed and cultivation density of shrimps during 50 days.

\begin{tabular}{|c|c|c|c|}
\hline Feed regimen & \multicolumn{3}{|c|}{ Final average weight \pm confidence Interval (g) } \\
\hline With feed & \multicolumn{3}{|c|}{$14.71 \pm 1.62^{\mathrm{a}}$} \\
\hline Without feed & \multicolumn{3}{|c|}{$13.59 \pm 1.22^{\mathrm{a}}$} \\
\hline Cultivation density & \multicolumn{3}{|c|}{ Final average weight \pm confidence Interval (g) } \\
\hline 05 shrimps $\mathrm{m}^{-2}$ & \multicolumn{3}{|c|}{$14.76 \pm 1.49^{\mathrm{a}}$} \\
\hline 10 shrimps $\mathrm{m}^{-2}$ & \multicolumn{3}{|c|}{$14.15 \pm 1.11^{\mathrm{a}}$} \\
\hline 15 shrimps $\mathrm{m}^{-2}$ & \multicolumn{3}{|c|}{$13.54 \pm 1.42^{\mathrm{a}}$} \\
\hline Interaction & \multicolumn{3}{|c|}{ Final average weight \pm confidence Interval $(\mathrm{g})$} \\
\hline Feed / density & 05 shrimps $\mathrm{m}^{-2}$ & 10 shrimps $\mathrm{m}^{-2}$ & 15 shrimps $\mathrm{m}^{-2}$ \\
\hline With feed & $15.50 \pm 1.66^{\mathrm{aA}}$ & $14.71 \pm 1.23^{\mathrm{aA}}$ & $14.71 \pm 1.52^{\mathrm{aA}}$ \\
\hline Without feed & $14.02 \pm 1.23^{\mathrm{aA}}$ & $13.59 \pm 0.99^{\mathrm{aA}}$ & $13.16 \pm 1.33^{\mathrm{bA}}$ \\
\hline
\end{tabular}

Same lowercase letters vertically represent statistical equality $\mathrm{p}>0.05$; Same uppercase letters horizontally represent statistical equality $\mathrm{p}>0.05$.

The highest average final weight $(15.50 \pm 1.66$ g) was found in the treatment with the lowest density that received feed (WIF05). Spanghero et al. (2008) also found that the density is a variable that negatively affects the final average weight of shrimps, while modeling animal production results of commercial cultivations of Litopenaeus vannamei in oligohaline and salt water in northeastern Brazil.

The shrimp grown without feed are dependent on the natural food in the nurseries to develop, and this food may be quickly consumed as the shrimp biomass increases. According to Nunes \& Parsons (2000), the natural food in the nurseries can contribute with 25 to $85 \%$ of the diet of farmed shrimp. The ratio biomass/cultivation density is very narrow, as the cultivation density increase the biomass tend to increase, and the consumption of the natural food available in the nursery is very fast in the absence of feed. According Tidwell et al. (1997), the shrimp may consume up to $38 \%$ of the macroinvertebrates population in the nurseries.

Roy et al. (2012) conducted weight gain tests with juvenile shrimp $(6.34 \mathrm{~g})$ in low salinity water for 9 weeks with different feed rates in two cultivation systems, with water exchange (continuous system) and without water exchange (static system), and found that the shrimps had a weekly growth rate of $1.50 \mathrm{~g}$ in the continuous system without feed and had a weight reduction $(5.55 \mathrm{~g})$ in the static system (without water exchange and feed). They attributed this difference to the introduction of natural food by the continuous system of water exchange, denoting the importance of natural food in the development of farmed shrimp and that the continued presence of natural food in the ponds is essential to meet the nutritional demand of shrimps in the absence of feed.

The daily weight gains of the treatments 
ranged from 0.0719 to $0.1488 \mathrm{~g} \mathrm{day}^{-1}$, with the lowest in the treatment WOF15 and the greatest in the WIF05. The average daily weight gain was $0.1152 \mathrm{~g} \mathrm{dia}^{-1}$, which corresponds to a mean weekly weight gain of $0.80 \mathrm{~g} \mathrm{week}^{-1}$ (Table 3). Miranda et al. (2010) found daily weight gains of 0.113 g.dia ${ }^{-1}$, with an initial density of 40 shrimps $\mathrm{m}^{-2}$ in a water of low salinity.

Similar result was found by Mariscal-Lagarda et al. (2012) with 50 shrimps $\mathrm{m}^{-2}$ and water salinity of $0,6 \mathrm{~g} \mathrm{~L}^{-1}$. However, Mariscal-Largada et al. (2010) found a higher average daily gain $\left(0.201 \mathrm{~g}^{\mathrm{dia}}{ }^{-1}\right)$ with water salinity of $1.8 \mathrm{~g} \mathrm{~L}^{-1}$ at lower cultivation density (13 shrimps $\mathrm{m}^{-2}$ ) of L. vannamei. This difference may be related to the L. vannamei genetic strain used in the experiments, since the strains used in Brazil show low performances, which are related to the genetic recombination in laboratories, once the import of new reproducers are prohibited since 1998 (FREITAS, et al. 2007)

The lowest daily weight gain found in this work are related to the treatments without feed, which had an average of $0.093 \mathrm{~g} \mathrm{dia}^{-1}$, since treatments with feed, in normal cultivation conditions, had an average of $0.138 \mathrm{~g} \mathrm{dia}^{-1}$.

A significant difference in daily average weight gain of shrimp was found, despite the weight gain model as a function of time for the feed treatments were equal. The treatment WIF10 was statistically equal to the WIF05 and WIF15 treatments, but different from each other, confirming the negative influence of density on the growth of shrimps.

Table 3. Weight gain models between treatments.

\begin{tabular}{ccccc}
\hline Treatments & $\begin{array}{c}\text { Models } \\
\mathrm{P}=\beta_{0}+\beta_{1} \mathrm{t}\end{array}$ & $\mathrm{R}^{2}$ & \multicolumn{2}{c}{ Statistic } \\
\cline { 4 - 5 } & $\mathrm{p}=7.6316+0.1488 \mathrm{t}$ & 0.9328 & Parameter $\beta_{1}{ }^{*}$ & Model ** \\
WIF05 & $\mathrm{p}=8.0516+0.1429 \mathrm{t}$ & 0.9836 & $\mathrm{~b} g$ & $\mathrm{a}$ \\
WIF10 & $\mathrm{p}=8.4795+0.1210 \mathrm{t}$ & 0.9707 & $\mathrm{bde}$ & $\mathrm{a}$ \\
WIF15 & $\mathrm{p}=8.1765+0.1105 \mathrm{t}$ & 0.9659 & $\mathrm{abc}$ & $\mathrm{b}$ \\
WOF05 & $\mathrm{p}=8.4829+0.0966 \mathrm{t}$ & 0.9154 & $\mathrm{adg}$ & $\mathrm{bc}$ \\
WOF10 & $\mathrm{p}=8.7845+0.0719 \mathrm{t}$ & 0.8936 & $\mathrm{a}$ & $\mathrm{c}$ \\
WOF15 &
\end{tabular}

*Different letters between the parameters $\beta_{1}$ denote statistical difference $(\mathrm{p}<0.05)$ using the $\mathrm{t}$-distribution. Where $\beta_{1}$ is the parameter that represents the daily weight gain. ${ }^{* *}$ Different letters between the models denote statistical difference $(\mathrm{p}<0.05)$ using the statistical $\mathrm{W}$, with $\chi^{2}$ distribution.

The daily weight gains (DWG) are presented in the models by the $B_{1}$ parameter. All treatments without feed (WOF) had equal statistically $(\mathrm{p} \geq 0.05)$ daily gains. The daily weight gain of WOF05 was equal to the WIF15 and WIF10 treatments, denoting the possibility of cultivation at low densities in the fattening stage without feed, without compromising the performance of the shrimp. These results imply that it may be a good management alternative for local producers with low financial resources (Figure 2).

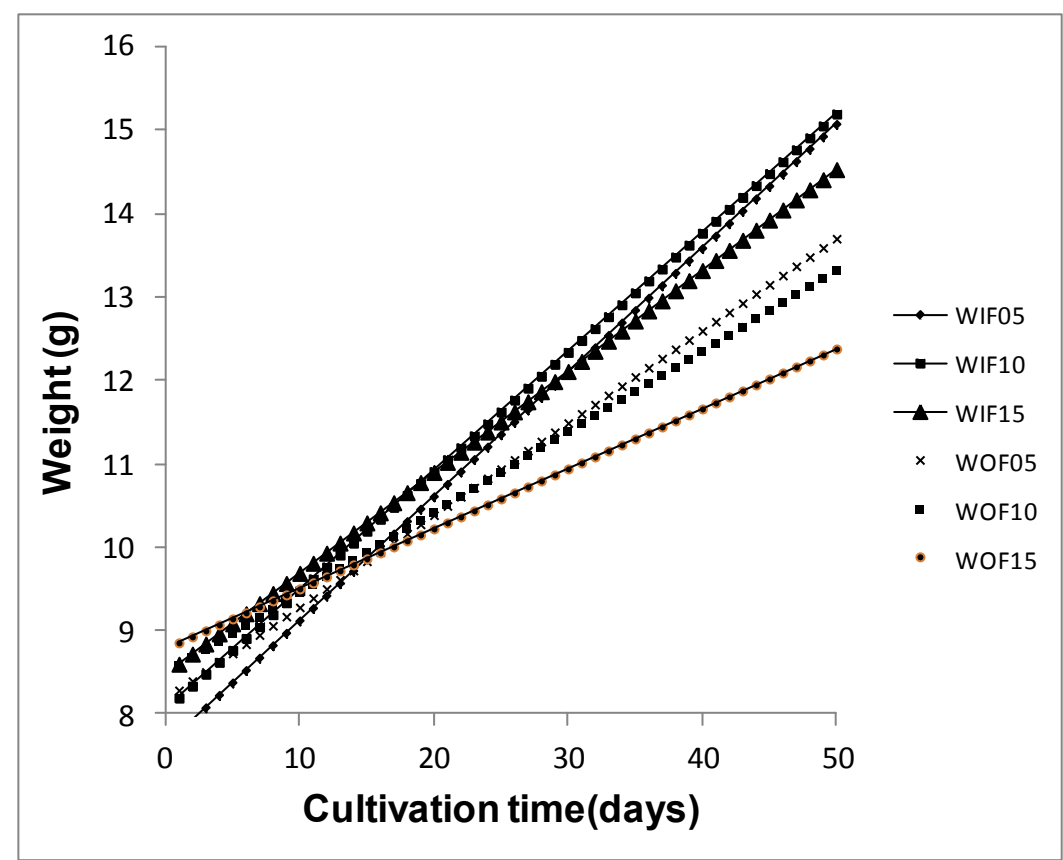

Figure 2. Graphical representation of weight gain models of different experimental treatments for Litopenaeus vannamei after 50 days of cultivation.

Rev. Caatinga, Mossoró, v. 29, n. 3, p. 700 - 708, jul. - set., 2016 
Survival rate

Based on the final number of shrimps in each net after 50 days of cultivation, the final survival rate (\%) ranged from $60.56 \pm 6.76 \%$ (WOF15) to $83.00 \pm 4.00 \%$ (WIF15). No significant difference ( $\mathrm{p} \geq 0.05$ ) was found between survival rates by testing the effect of the use or not of feed or the effect of different densities.

No difference $(\mathrm{p}<0.05)$ in survival at densities of 10 and 15 shrimps $\mathrm{m}^{-2}$ was found when the treatments were individually analyzed, even considering the factor of use or not of feed (Table 4).

Table 4. Survival rate (\%) depending on the supplying or not of feed and cultivation density of shrimps during 50 days.

\begin{tabular}{|c|c|c|c|}
\hline Feed regimen & \multicolumn{3}{|c|}{ Survival rate \pm Confidence interval (\%) } \\
\hline With feed & \multicolumn{3}{|c|}{$71.44 \pm 5.68^{\mathrm{a}}$} \\
\hline Without feed & \multicolumn{3}{|c|}{$72.94 \pm 5.21^{\mathrm{a}}$} \\
\hline Cultivation density & \multicolumn{3}{|c|}{ Survival rate \pm Confidence interval (\%) } \\
\hline 05 shrimps $\mathrm{m}^{-2}$ & \multicolumn{3}{|c|}{$73.00 \pm 7.02^{\mathrm{a}}$} \\
\hline 10 shrimps $\mathrm{m}^{-2}$ & \multicolumn{3}{|c|}{$62.10 \pm 6.85^{\mathrm{a}}$} \\
\hline 15 shrimps $\mathrm{m}^{-2}$ & \multicolumn{3}{|c|}{$69.50 \pm 6.75^{\mathrm{a}}$} \\
\hline Interaction & \multicolumn{3}{|c|}{ Survival rate \pm Confidence interval $(\%)$} \\
\hline Feed/density & 05 shrimps $\mathrm{m}^{-2}$ & 10 shrimps $\mathrm{m}^{-2}$ & shrimps $\mathrm{m}^{-2}$ \\
\hline With feed & $61.00 \pm 9.00^{\mathrm{aA}}$ & $70.33 \pm 10.58^{\mathrm{aAB}}$ & $83.00 \pm 4.00^{\mathrm{aB}}$ \\
\hline Without feed & $81.00 \pm 7.57^{\mathrm{bA}}$ & $77.25 \pm 10.55^{\mathrm{aAB}}$ & $60.56 \pm 6.76 b^{\mathrm{B}}$ \\
\hline
\end{tabular}

Same lowercase letters vertically represent statistical equality $p>0.05$; Same uppercase letters horizontally represent statistical equality $\mathrm{p}>0.05$.

According to the water quality evaluations (each 15 days), the water salinity were close to $1.0 \mathrm{~g}$ $\mathrm{L}^{-1}$, alkalinity was greater than $150 \mathrm{mg} \mathrm{L}^{-1}$ of $\mathrm{CaCO}_{3}$, hardness was $140 \mathrm{mg} \mathrm{L}^{-1}$, and $\mathrm{pH}$ tended to be alkaline, ranging from 6.5 to 9.7 . The average temperature was higher than $28^{\circ} \mathrm{C}$ and the dissolved oxygen higher than and $5.0 \mathrm{mg} \mathrm{L} \mathrm{L}^{-1}$. The concentrations of nitrogen and phosphorus did not exceed the desired levels throughout the cultivation (Table 5).

Many works evaluate the water quality effect in shrimp cultivations with low salinity water on the survival rate, however, the more discussed issue is related to the ionic composition and balance of waters. Godíniz-Siordia et al. (2011) emphasize the importance of the presence and concentration of the ions chloride, calcium, magnesium sulfate and potassium to generate a good survival rate of organisms grown at low salinity waters.

Angulo et al. (2005) stated that the ionic composition of the water is crucial for a good survival rate of shrimps in low salinity waters and that the potassium is the main one. According to Valenzuela et al. (2010) and Esparza-Leal et al. (2009), a good ratio of ions $\mathrm{Na} / \mathrm{K}$ is $37.91: 1$ and $\mathrm{Mg}$ / $\mathrm{K}$ is $3.68: 1$. These amounts would be enough to obtain good growth results and survival rates of shrimps grown in low salinity waters.

The ions ratio of $\mathrm{Na} / \mathrm{K}(7.94: 1)$ and $\mathrm{Mg} / \mathrm{K}$ (1.96:1) during the experiment (Table 5) were below those recommended by Valenzuela et al. (2010) and Esparza-Leal et al. (2009), however, the results of growth and survival rate were satisfactory in the Brazilian semiarid region. Mariscal-Largada et al. (2012) found ratio of $\mathrm{Na} / \mathrm{K}$ of $15.4: 1, \mathrm{Ca} / \mathrm{K}$ of $6.1: 1$ and $\mathrm{Mg} / \mathrm{Ca}$ of $1: 2.7$ growing $L$. vannamei in water of low salinity $\left(0.6 \mathrm{~g} \mathrm{~L}^{-1}\right)$, resulting in a survival rate of $56.3 \%$, which was lower than the results from the present work. Despite the ratio of $\mathrm{Na} / \mathrm{K}(7.94: 1)$ in the present work, the survival and growth results were satisfactory compared to the other studies previously cited.

Table 5. Average and standard deviation of hydrological parameters during the experimental cultivation of L. vannamei in oligohaline waters.

\begin{tabular}{lcccc}
\hline Parameters & $\begin{array}{c}\text { Nurseries } \\
\text { Average } \pm \text { Standard } \\
\text { deviation }\end{array}$ & Variation & $\begin{array}{c}\text { Reference } \\
\text { values }(1)\end{array}$ & $\begin{array}{c}\text { Reference } \\
\text { values (2) }\end{array}$ \\
\hline Temperature $\left({ }^{\circ} \mathrm{C}\right)$ & $28.09 \pm 0.06$ & $22.59-33.15$ & $28.00-32.00$ & \\
Dissolved oxygen $\left(\mathrm{mg} \mathrm{L}^{-1}\right)$ & $6.10 \pm 0.08$ & $1.01-13.47$ & $5.00-9.00$ & $7.00-8.30$ \\
$\mathrm{pH}$ & $8.48 \pm 0.01$ & $6.50-9.77$ & $7.00-8.00$ \\
Salinity $\left(\mathrm{g} \cdot \mathrm{L}^{-1}\right)$ & $0.99 \pm 0.00$ & $0.89-1.06$ & & \\
Conductivity $\left(\mu \mathrm{S} \mathrm{Cm}^{-1}\right)$ & $1,972 \pm 1.4238$ & $1,798-2,106$ & & \\
Nitrate $\left(\mu \mathrm{g} \mathrm{L}{ }^{-1}\right)$ & $2.63 \pm 1.07$ & $0.03-11.16$ & \\
Nitrite $\left(\mu \mathrm{g} \mathrm{L}^{-1}\right)$ & $2.30 \pm 0.51$ & $0.60-6.00$ & \\
Ammonia $\left(\mu \mathrm{g} \mathrm{L}{ }^{-1}\right)$ & $5.79 \pm 4.90$ & $0.00-59.19$ & & \\
\hline
\end{tabular}

(1)Van Wyk \& Scarpa (1999); (2) Boyd et al., 2002. 
Table 5. continuation.

\begin{tabular}{|c|c|c|c|c|}
\hline Parameters & $\begin{array}{c}\text { Nurseries } \\
\text { Average } \pm \text { Standard } \\
\text { deviation }\end{array}$ & Variation & $\begin{array}{l}\text { Reference } \\
\text { values (1) }\end{array}$ & $\begin{array}{l}\text { Reference } \\
\text { values (2) }\end{array}$ \\
\hline Orthophosphate $\left(\mu \mathrm{g} \mathrm{L}^{-1}\right)$ & $46.35 \pm 3.41$ & $34.58-77.81$ & & \\
\hline Chlorophyll-a $\left(\mu \mathrm{g} \mathrm{L}^{-1}\right)$ & $47.99+6.49$ & $17.27-84.41$ & & \\
\hline Phaeophytin $\left(\mu \mathrm{g} \mathrm{L}^{-1}\right)$ & $26.20 \pm 3.71$ & $6.64-47.21$ & & \\
\hline Alkalinity $\left(\mathrm{mg} \mathrm{L}^{-1}\right)$ & $226.65 \pm 9.25$ & $151.5-261.00$ & $<100.00$ & 70.00 \\
\hline Calcium (mg L $\left.{ }^{-1}\right)$ & $21.65 \pm 1.36$ & $16.03-29.98$ & $>100.00$ & $11.00-296.00$ \\
\hline Magnesium (mg L-1) & $51.91 \pm 2.86$ & $22.76-60.80$ & $>50.00$ & $3.00-64.00$ \\
\hline Total hardness $\left(\mathrm{mg} \mathrm{L}^{-1}\right)$ & $267.73 \pm 12.38$ & $147.74-305.09$ & $>150.00$ & \\
\hline Turbidity NTU & $17.70 \pm 1.97$ & $9.00-33.10$ & & \\
\hline Chlorides $\left(\mathrm{mg} \mathrm{L}^{-1}\right)$ & $426.92 \pm 23.68$ & $175.00-500.00$ & $>300.00$ & $380.00-4,009.00$ \\
\hline Silica $\left(\mathrm{mg} \mathrm{L}^{-1}\right)$ & $0.66 \pm 0.09$ & $0.36-1.29$ & & \\
\hline Potassium (mg L $\left.{ }^{-1}\right)$ & $26.37 \pm 0.69$ & $21.50-31.60$ & & $4.00-12.40$ \\
\hline Sodium $\left(\mathrm{mg} \mathrm{L}^{-1}\right)$ & $209.49 \pm 4.33$ & $170.20-223.10$ & $>200.00$ & $401.00-2,210.00$ \\
\hline Total sulphate $\left(\mathrm{mg} \mathrm{L}^{-1}\right)$ & $3.43 \pm 0.58$ & $1.20-9.10$ & & \\
\hline \multicolumn{5}{|l|}{ Proportion } \\
\hline $\mathrm{Na} / \mathrm{K}$ & $7.94: 1$ & & & \\
\hline $\mathrm{Mg} / \mathrm{K}$ & $1.96: 1$ & & & \\
\hline $\mathrm{Mg} / \mathrm{Ca}$ & $3.39: 1$ & & & \\
\hline $\mathrm{Ca} / \mathrm{K}$ & $0.82: 1$ & & & \\
\hline
\end{tabular}

(1)Van Wyk and Scarpa (1999); (2) Boyd et al., 2002.

Mariscal-Largada et al. (2010) conducted cultivations with four different quality of low salinity well waters $\left(0.52\right.$ to $\left.0.88 \mathrm{~g} \mathrm{~L}^{-1}\right)$ and a control with salt water $\left(34 \mathrm{~g} \mathrm{~L}^{-1}\right)$, and found the lowest survival rate $(76.35 \pm 3.69)$ in the treatment with salinity of 0.72 , which had the highest proportion of $\mathrm{Ca} / \mathrm{K}$ (49.1:1), denoting a deficiency in $\mathrm{K}$ compared to other ions, confirming what was reported by Zhu et al. (2004), who found low survival of L. vannamei when the $\mathrm{Na} / \mathrm{K}$ ratio was high in seawater.

The shrimps grown in the hydro-climatic conditions of the Pernambuco semiarid region has managed to compensate for the deficiency of some nutrients or ions to maintain its osmotic balance without requiring much energy, since good growth and survival rates were found. This compensatory mechanism may be activated by the natural feed or by mineral sources from the nursery soils.

Most water quality variables were within the values recommended by Van Wyk \& Scarpa (1999) e Boyd et al., (2002), and when not within their recommended ranges, they were close. No mortality due to the decline in water quality was found. The mortality occurred may be related to the stress at transference to the plots and predation by birds and amphibians. The mortality during cultivation could not be evaluated, since the experiment was carried out on land ponds, where a daily visually accounting is not possible, as performed in experiments in aquariums.

\section{CONCLUSION}

All treatments provided good results of growth and survival in the water and climatic conditions of the Pernambuco semiarid region. No interventions on the water quality, regarding its ionic composition was needed. Further studies with new sources of water and diagnosis of technical and economic feasibility are needed in order to confirm the activity as an alternative for the aquaculture in the region.

\section{ACKNOWLEDGEMENTS}

The authors thank the UFRPE and FACEPE for the structural and financial support for the development of this research, the Agronomic Institute of Pernambuco (IPA) for the facilities and staff for this work, the Undergraduate students of Fisheries Engineering of the Academic Unit of Serra Talhada, who collaborated with field and laboratory activities as volunteers over eight months of work. 


\section{REFERENCES}

ABCC. Associação Brasileira de Criadores de Camarão. O censo da carcinicultura nacional em 2011. Revista da Associação Brasileira de Criadores de Camarão, Natal, v. 15, n. 1, p. 24 28, 2013

ANGUlO, J. A.; MEJÍA, A.; ENGEL, R. Cultivo experimental de camarón blanco Litopenaeus vannamei en el valle del Mezquital, Panorama Acuícola, Hidalgo, v. 10, p. 10-15, 2005.

BOYD, C. E.; THUNJAI, T.; BOONYARATPALIN, M. Dissolved salts in waters for inland low- salinity shrimp culture. Global Aquaculture Advocate. St. Louis, v. 5, n. 3, p. 40-45, 2002.

CAMPOS, S. S. et al. Natural food evaluation and water quality in zero water exchange culture of Litopenaeus vannamei fertilized with wheat bran. Aquaculture International, Amsterdam, v. 17, n. 2, p. 113-124, 2009.

COSTA, M. R.; CIRILO, J.A. Análise do Potencial de Uso das Águas Subterrâneas nas Bacias da Região Semi-árida. In: Congresso Brasileiro de Águas Subterrâneas e Encontro Nacional de Perfuradores de Poços, 16., 17., 2010, São Luis. Anais... São Luis: ABAS, 2010. p. 1-13.

CPRM, Projeto Cadastro de Fontes de Abastecimento por Água Subterrânea, Pernambuco. out. 2005.

CUZON, G. et al. Nutrition of Litopenaeus vannamei reared in tanks or in ponds. Aquaculture, Amsterdam, v. 235, n. 1, p. 513-551, 2004.

DAVIS, D. A.; BOYD, C. E.; ROUSE, D. B. Effects of potassium, magnesium and age on growth and survival of Litopenaeus vannamei post-larvae reared in inland low salinity well waters in West Alabama. Journal of World Aquaculture Society, Baton Rouge, v. 36, n. 3, p. 416-419, 2005.

ESPARZA-LEAL H. M. et a l. The effect of low salinity water with different ionic composition on the growth and survival of Litopenaeus vannamei (Boone, 1931) in intensive culture. Journal of Applied Aquaculture, v. 21, n. 4, p. 215-227, 2009.

FAO. Fishery Information, Data and Statistics Unit. FishStat Plus: Universal software for fishery statistical time series. Version 2.3. Rome, 2014. Disponível em: <http://www.fao.org/fi/statist/ FISOFT/FISHPLUS.asp>. Acesso em: 27 julho 2014.
FREITAS, P. D.; CALGARO, M. R.; GALETTI JR, P. M. Genetic diversity within and between broodstocks of the white shrimp Litopenaeus vannamei (Boone, 1931) (Decapoda, Penaeidae) and its implication for the gene pool conservation. Brazilian Journal of Biology, São Carlos, v. 67, n. 4, p. 939-943, 2007.

GODÍNEZ-SIORDIA, D. E.; CHÁVEZ-SÁNCHEZ, M. C.; GÓMEZ-JIMÉNEZ, S. Acuicultura epicontinental del camarón blanco del pacífico, Litopenaeus vannamei (BOONE, 1931). Tropical and Subtropical Agroecosystems, Mérida, v. 14, n. 1, p. 55-62, 2011.

MARISCAL-LAGARDA, M. M.; ESQUERMÉNDES, J. L.; PÁEZ-OSUNA, F. Shrimp study uses low-salinity groundwater in Sonora, Mexico. Global Aquaculture Advocate, St. Louis, v. 13, n. 3, p. 42-43, 2010.

MARISCAL-LAGARDA, M. M. et al. Integrated culture of white shrimp (Litopenaeus vannamei) and tomato (Lycopersion esculentum Mill) with low salinity groundwater: Management and production. Aquaculture, Amsterdam, v. 366-367, n. 5, p. 7684, 2012.

MENDES, P. P.; MENDES, E. S.; BEZERRA, A. M. Análise estatística dos parâmetros aquícolas, com fins a otimização da produção. Revista Brasileira de Zootecnia (Suplemento especial), Viçosa, v. 35, p. 886-903, 2006

MIRANDA, I. et al. Cultivo del camarón marino (BOONE, 1931) em agua dulce. Revista Cientifica, São Paulo, v. 20, n. 4, p. 339-346, 2010.

NUNES, A. J. P.; PARSONS G. J. Effects of the Southern brown shrimp, Penaeus subtilis, predation and artificial feeding on the population dynamics of bentic polychaetes in tropical pond enclosures. Aquaculture, Amsterdam, v. 183, n. 1-2, p. $125-$ 147,2000

ROY, L. A.; DAVIS, D. A.; WHITIS, G. N. Effect of feeding rate and pond primary productivity on growth of Litopenaeus vannamei reared in inland saline waters of West Alabama, North American Journal of Aquaculture, London, v. 74, n. 1, p. 2026,2012

SPANGHERO, D. B. N. et al. Utilização de modelos estatísticos para avaliar dados de produção do camarão Litopenaeus vannamei cultivados em águas oligohalina e salgada. Acta Scientiarum. Animal Sciences, Maringá, v. 30, p. 451-458, 2008

TIDWELL, J. H. et al. Relative prawn production and benthic macro-invertebrate densities in unfed, 
organically fertilized, and fed pond systems. Aquaculture, Amsterdam, v. 149, n. 3-4, p. 227242, 1997.

VALENZUELA, W.; RODRÍGUEZ, G.; H. ESPARZA. Cultivo intensivo de camarón blanco Litopenaeus vannamei (Boone) en agua de pozo de baja salinidad como alternativa acuícola para zonas de alta marginación. Revista Ra Ximhai, Mochicahui, v. 6, n. 1, p. 1-8, 2010.

VAN WYK, P.; SCARPA, J. Water quality requirement and management. In: VAN WYK, J. et al. Farming Marine Shrimp in Recirculating Freshwater Systems, Florida: Harbor branch Oceanographic Institution, 1999. cap. 8, p. 141-162.

YE, L. et al. Effects of salinity on growth and energy budget of juvenile Penaeus monodon. Aquaculture, Amsterdam, v. 290, n. 1-2,p. 140-144. 2009.

ZAR, J. H. Biostatistical Analysis. 5. ed. Upper Sadle River, NJ: Pearson Prentice-Hall, 2010. 944 p.

ZHU C, et al. Effects of $\mathrm{Na} / \mathrm{K}$ ratio in seawater on growth and energy budget of juvenile Litopenaeus vannamei. Aquaculture, Amsterdam, v. 234, n. 1-4, p. 485-496, 2004. 